Enzyme Activities and Folate Levels in Rats Treated with Anticonvulsant Drugs

\begin{tabular}{|c|c|c|c|c|c|c|c|c|c|c|c|c|c|c|c|}
\hline \multirow{4}{*}{$\begin{array}{l}\text { Exp. } \\
\text { No. }\end{array}$} & \multirow{4}{*}{\multicolumn{2}{|c|}{$\begin{array}{l}\text { Sex and } \\
\text { Number } \\
\text { of rats }\end{array}$}} & \multirow{4}{*}{$\begin{array}{c}\begin{array}{c}\text { Folic } \\
\text { Acid }\end{array} \\
1 \mathrm{mg} / \mathrm{kg} \\
\text { diet }\end{array}$} & \multicolumn{2}{|c|}{ Phenobarbitone } & \multirow{4}{*}{$\begin{array}{l}\mathrm{DPH} \dagger \\
1 \mathrm{~g} / \mathrm{kg}\end{array}$} & \multirow{4}{*}{$\begin{array}{c}\text { Pheno- } \\
\text { barbitone } \\
\text { +DPH } \\
0.5 \mathrm{~g} / \mathrm{kg} \\
\text { each }\end{array}$} & \multirow{2}{*}{\multicolumn{2}{|c|}{$\begin{array}{l}\text { Glutamate } \\
\text { formimino- } \\
\text { transferase }\end{array}$}} & \multirow{2}{*}{\multicolumn{2}{|c|}{$\begin{array}{c}\text { Methylene } \\
\text { tetrahydrofolate } \\
\text { dehydrogenase }\end{array}$}} & \multirow{3}{*}{\multicolumn{2}{|c|}{$\begin{array}{l}\text { Serum folate } \\
(\mathrm{ng} / \mathrm{ml})\end{array}$}} & \multirow{3}{*}{\multicolumn{2}{|c|}{$\begin{array}{l}\text { Liver folate } \\
\begin{array}{c}(\mu \mathrm{g} / \mathrm{g} \text { wet } \\
\text { liver })\end{array}\end{array}$}} \\
\hline & & & & \multirow{3}{*}{$1 \mathrm{~g} / \mathbf{k g}$} & \multirow{3}{*}{$\begin{array}{c}4 \text { or } 8 \mathrm{mg} \\
\text { by } \\
\text { injection } \\
\text { daily }\end{array}$} & & & & & & & & & & \\
\hline & & & & & & & & \multicolumn{4}{|c|}{ (Units $/ 100 \mathrm{~g}$ body weight) } & & & & \\
\hline & & & & & & & & Mean & S.D. & Mean & S.D. & Mean & S.D. & Mean & S.D. \\
\hline 1 & & $\begin{array}{l}10 \\
10 \\
10 \\
10\end{array}$ & $\begin{array}{l}0 \\
0 \\
+ \\
+\end{array}$ & $\begin{array}{l}0 \\
+ \\
0 \\
+\end{array}$ & $\begin{array}{l}0 \\
0 \\
0 \\
0\end{array}$ & $\begin{array}{l}0 \\
0 \\
0 \\
0\end{array}$ & $\begin{array}{l}0 \\
0 \\
0 \\
0\end{array}$ & $\begin{array}{l}18 \cdot 3 \\
31 \cdot 3^{*} \\
17 \cdot 6 \\
33 \cdot 4^{*}\end{array}$ & $\begin{array}{l}3 \cdot 3 \\
5 \cdot 4 \\
3 \cdot 0 \\
5 \cdot 1\end{array}$ & $\begin{array}{c}8 \cdot 8 \\
11 \cdot 5^{*} \\
7 \cdot 9 \\
13 \cdot 8^{*}\end{array}$ & $\begin{array}{l}0 \cdot 8 \\
2 \cdot 3 \\
1 \cdot 3 \\
2 \cdot 1\end{array}$ & $\begin{array}{l}53 \cdot 8 \\
33 \cdot 0^{*} \\
86 \cdot 0 \\
30 \cdot 0^{*}\end{array}$ & $\begin{array}{l}24 \\
13 \\
16 \\
11\end{array}$ & $\begin{array}{r}7 \cdot 1 \\
8.9 \\
11 \cdot 7 \\
8.9\end{array}$ & $\begin{array}{l}1 \cdot 8 \\
3 \cdot 9 \\
3 \cdot 2 \\
1 \cdot 8\end{array}$ \\
\hline \multirow[b]{2}{*}{2} & & $\begin{array}{l}7 \\
7\end{array}$ & + & $\begin{array}{l}0 \\
0\end{array}$ & $\begin{array}{l}0 \\
+\end{array}$ & $\begin{array}{l}0 \\
0\end{array}$ & $\begin{array}{l}0 \\
0\end{array}$ & $\begin{array}{l}23 \cdot 7 \\
49 \cdot 0^{*}\end{array}$ & $\begin{array}{l}3.6 \\
8.7\end{array}$ & $\begin{array}{l}10 \cdot 3 \\
17 \cdot 0\end{array}$ & $\begin{array}{l}1 \cdot 2 \\
1.9\end{array}$ & \multirow{2}{*}{\multicolumn{2}{|c|}{$\begin{array}{l}z \\
z\end{array}$}} & \multirow{2}{*}{\multicolumn{2}{|c|}{$\begin{array}{l}= \\
=\end{array}$}} \\
\hline & $\mathbf{M}$ & $\begin{array}{l}6 \\
6\end{array}$ & + & $\begin{array}{l}0 \\
0\end{array}$ & $\begin{array}{l}0 \\
+ \\
\end{array}$ & $\begin{array}{l}0 \\
0 \\
\end{array}$ & $\begin{array}{l}0 \\
0 \\
\end{array}$ & $\begin{array}{l}20 \cdot 8 \\
32 \cdot 6^{*}\end{array}$ & $\begin{array}{l}2 \cdot 4 \\
2 \cdot 4 \\
\end{array}$ & $\begin{array}{c}7 \cdot 4 \\
11 \cdot 1^{*}\end{array}$ & $\begin{array}{l}0.5 \\
2.5 \\
\end{array}$ & & & & \\
\hline 6 & $\mathbf{M}$ & $\begin{array}{l}7 \\
7 \\
7 \\
\end{array}$ & $\begin{array}{l}0 \\
0 \\
0 \\
\end{array}$ & $\begin{array}{l}0 \\
0 \\
0 \\
\end{array}$ & $\begin{array}{l}0 \\
0 \\
0 \\
\end{array}$ & $\begin{array}{l}0 \\
0 \\
+ \\
\end{array}$ & $\begin{array}{l}0 \\
+ \\
0 \\
\end{array}$ & $\begin{array}{l}12 \cdot 7 \\
32.0^{*} \\
15 \cdot 6^{*}\end{array}$ & $\begin{array}{l}1.5 \\
4.5 \\
1 \cdot 1 \\
\end{array}$ & $\begin{array}{c}7 \cdot 4 \\
11 \cdot 1 * \\
8 \cdot 0\end{array}$ & $\begin{array}{l}1 \cdot 3 \\
1.3 \\
1.1 \\
\end{array}$ & $\begin{array}{l}17 \cdot 5 \\
14 \cdot 6 \\
13 \cdot 5 \\
\end{array}$ & $\begin{array}{l}9 \cdot 7 \\
8 \cdot 6 \\
7 \cdot 8 \\
\end{array}$ & $\begin{array}{l}7 \cdot 1 \\
8 \cdot 2 \\
5 \cdot 0^{*} \\
\end{array}$ & $\begin{array}{l}1.5 \\
2.5 \\
0.9 \\
\end{array}$ \\
\hline 7 & $\mathbf{M}$ & $\begin{array}{l}5 \\
5 \\
5\end{array}$ & $\begin{array}{l}+ \\
+ \\
+\end{array}$ & $\begin{array}{l}0 \\
0 \\
0\end{array}$ & $\begin{array}{l}0 \\
0 \\
0\end{array}$ & $\begin{array}{l}0 \\
0 \\
+\end{array}$ & $\begin{array}{l}0 \\
+ \\
0\end{array}$ & $\begin{array}{l}12 \cdot 0 \\
24 \cdot 7^{*} \\
13 \cdot 5\end{array}$ & $\begin{array}{l}2 \cdot 1 \\
2 \cdot 7 \\
4 \cdot 8\end{array}$ & $\begin{array}{c}8 \cdot 1 \\
10 \cdot 4^{*} \\
6 \cdot 8\end{array}$ & $\begin{array}{l}1.8 \\
1.0 \\
1.5\end{array}$ & $\begin{array}{l}30 \cdot 4 \\
24 \cdot 5 \\
37 \cdot 7\end{array}$ & $\begin{array}{r}26 \\
9 \\
20\end{array}$ & $\begin{array}{l}10 \cdot 1 \\
12 \cdot 0 \\
10 \cdot 1\end{array}$ & $\begin{array}{l}2.5 \\
4.7 \\
2.5\end{array}$ \\
\hline
\end{tabular}

* Mean significantly different from the mean for the conrol animals at the $5 \%$ level or more
+ Diphenylhydantoin

+ Diphenylhydantoin

These results support the hypothesis of Dr. Maxwell and his colleagues. They have not yet been prepared for detailed publication, but a full account of the experiments is available. ${ }^{1}-\mathrm{We}$ are, etc.,

Nuffield Department of Clinical Medicine, Radcliffe Infirmary,

Oxford

G. H. SPRAY

Department of Medicine,

Groote Schuur Hospital,

Cape Town,

1 Burns, D. G., thesis, University of Oxford, 1968. Burns, D. G., and Spray, G. H., British fournal
of Nutrition, 1969, 23. 665 . Histolical Chemistry, 1957, 227, 805. 17,660. H., foumal of Clinical Pathology, 1964, Bennett, M. C., Berry, V., Chanarin, I., and
Ardeman, S., fournal of Clinical Pathology,
1964, 17, 27.

\section{Hepatotoxicity of Sulphamethoxypyridazine}

SIR,-Hepatotoxic properties are considered to be uncommon in the newer sulphonamides. The development of jaundice concurrently with sulphonamide therapy may be from drug hepatitis, but there is also a risk of labelling a viral hepatitis as a sulphonamide hepatitis. The causal relationship of sulphomamides can promply be confirmed or excluded by a hypersensitivity reaction provoked by administration of a test dose. The causal relationship of the newer sulphonamides to hepatitis has been so established in five cases only. . $^{1-4}$ In the two cases observed in our clinic ${ }^{4}$ the causal agent was a combination of sulphamethoxypyridazine and sulphamethizole. Since then the same sulphonamide has been shown to be the cause of two further cases of hepatitis. All these four cases were observed in our clinic within 11 months. In one case the causal agent was confirmed to be sulphamethoxypyridazine.

A 34-year-old woman was admitted to the hospital because of jaundice while taking tablets containing $250 \mathrm{mg}$ of sulphamethoxypyridazine and $250 \mathrm{mg}$ of sulphamethizole for a urinary tract infection. The dose had been four tablets daily for three weeks. Previously she had been prescribed the same tablets twice without untoward effects. In addition she had been taking oral contraceptives for about one year. On admission all medication was withdrawn. Serum total bilirubin was $12.8 \mathrm{mg} / 100 \mathrm{ml}$ (conjugated 12.0); serum alkaline phosphatase was 60 IU/1. (upper limit of normal 46); and ornithine carbamoyltransferase $1.64 \mathrm{IU} / 1$. (upper limit of normal 0.40 ). Tests for urine bilirubin and urobilinogen were positive and for serum Au-antigen and alpha-fetoprotein negative. There were no signs of haemolysis judged haematologically or by serum haptoglobin concentration or serum lactic dehydrogenase isoenzyme determinations. There were no other relevant findings. After return to normal of the laboratory values test doses of sulphonamide components were given as shown (see Figure)

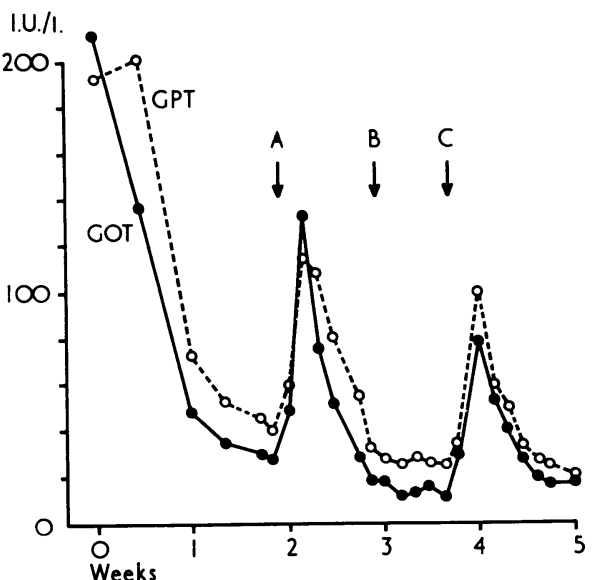

Serum aspartate aminotransferase (GOT) and alamine aminotransferase (GPT) responses when two tablets of sulphonamide containing $250 \mathrm{mg}$ of sul were given (A). At B $500 \mathrm{mg}$ of sulphamethizole and were given (A). At B $500 \mathrm{mg}$ of sulphamethizole and ministered orally.

It is evident that sulphamethoxypyridazine caused a similar rise of serum enzymes as the combination of the two sulphonamides, whereas on administration of sulphamethizole no reaction could be seen. The hypersensitivity reactions were milder in this patient than in the other patients tested by us. There was no rise in body temperature or serum bilirubin. Liver biopsy, performed after the last exhibition to sulphonamide, revealed nonspecific changes pointing to reactive hepatitis without intrahepatic cholestasis.

Since the patient had also taken oral contraceptives which might have contributed to the hepatitis, she was put back on the pill after discharge from the hospital. This was considered to be safe immediately after hepatitis on the basis of our earlier study. ${ }^{5}$ Serum enzyme activities remained normal during two menstrual cycles.

The occurrence of four cases of sulphonamide hepatitis within 11 months in one clinic which does not specialize in hepatic disease seems to indicate that this illness is more common than generally thought. In all our cases sulphamethoxypyridazine was one component and was confirmed to be the causal agent in the case tested. This sulphonamide seems to be specially hepatotoxic since, according to the present sales records, drugs containing this sulpha comprise only $29 \%$ of the total amount of sulphonamides sold in Finlä̀nd.-I am, etc.,

AARNE KONTTINEN

First Department of Medicine

University Centra

1 Fries, J., and Siraganian, R., New England Fournal' of Medicine, 1966, 274, 95. Dujovne, C. A., Chan, C. H., and Zimmerman,
H. J., New England fournal of Medicine, 1967, 277, 785 .

Kaufman, S. F., California Medicine, 1967, 107,

344.
Konttinen, A., Peräsalo, J., and Eisalo, A., Acta Eisalo, A., Konttinen, A., and Hietala, O., British Medical fournal, 1971, 3, 561.

\section{Australia Antigen in Chronic Liver Disease}

SIR,-The varying presence of Australia Antigen ( $\mathrm{Au}-\mathrm{Ag}$ ) in chronic liver diseases in different countries is now clearly established. ${ }^{1}$ In some the incidence is high and in others it is low or nil. It seems unlikely that these differences are due entirely to differences in laboratory techniques used, and they might be important in establishing the aetiology of chronic liver diseases in relation to different geographical conditions.

We have studied 126 cases of chronic liver disease, confirmed by biopsy, from a population with a high incidence of cryptogenic and posthepatitis cirrhosis compared with alcoholic cirrhosis. There was a very high incidence of $\mathrm{Au}-\mathrm{Ag}$ in chronic aggressive hepatitis both with complement fixation and immunodiffusion in agarose compared with a relatively low frequency in chronic persistent hepatitis (see Table). The incidence was also high in cases of posthepatitis and cryptogenic cirrhosis. 